Коровій Я.В.,

аспірант кафедри міжнародних економічних відносин, Донецький національний університет імені Василя Стуса ya.koroviy@donnu.edu.ua

Орсхова T.B., д.е.н., професор,

Донецький національний університет імені Василя Стуса ORCID: 0000-0003-3650-5935

t.oriekhova@donnu.edu.ua

\title{
ДОСЛІДЖЕННЯ ІННОВАЦИЙНОГО РОЗВИТКУ В АГРОПРОМИСЛОВОМУ ВИРОБНИЦТВІ ЯК ФАКТОРУ ЗАБЕЗПЕЧЕННЯ СТАЛОГО РОЗВИТКУ
}

У роботі проводиться дослідження впливу інновачійного розвитку агропромислового виробництва країн на їхній сталий розвиток. За базу аналізу було обрано 24 країни - найбільші експортери агропромислової продукиї, щуо розташовані практично на всіх континентах, та представляють різні групи за рівнем економічного розвитку. Шляхом застосування методу кластерного аналізу отримано три кластери країн: кластер 1 (Аргентина, Бразилія, Болгарія, Колумбія, Індія, Індонезія, Латвія, Мексика, Румунія, Тайланд, Туреччина, Украӥна), до якого входять краӥни з переважно аграрною економікою, щуо розвивається за екстенсивним шляхом розвитку з низьким рівнем врожайності, високими показниками частки сільськогосподарських угідь, низьким рівнем витрат на інновації, та відповідним низьким рівнем тривалості життя населення і ВВП на душу населення; збільшення витрат на інновації в циих краӥнах не має ефективного виливу на зростання доданої вартості у галузях агропромислового виробництва в иій групі країн; кластер 2 (Німеччина, Японія, Корея, Нідерланди, Швеція, Швейцарія), до якого входять краӥни з високого інновачійним агропромисловим сектором, який не має системо утворюючого значення у загальній структурі економіки, проте характеризується високим рівнем врожайності, низькою часткою витрат на ресурси, високим рівнем витрат на інновації, та відповідно - високими стандартами життя населення: тривалістю життя, ВВП на душу населення; кластер 3 (Австралія, Канада, Китай, Естонія, США), до якого входять краӥни з індустріальною та постіндустріальною структурою економіки, з високою кількістю населення, відповідно - з екстенсивною моделлю розвитку АПК, з високими стандартами життя населення, проте з високими показниками навантаження на екосистему.

Ключові слова: інноваційний розвиток, сталий розвиток, сільське господарство, агропромисловий комплекс, кластерний аналіз.

Рис. -3 , Табл. -9 , Літ. -5 


\section{Коровий Я.В.,}

аспирант кафедры международных экономических отношений, Донецкий национальный университет имени Васыля Стуса ya.koroviy@donnu.edu.ua

\section{Орехова T.B.,}

д.э.Н., профессор,

Донецкий национальный университет имени Васыля Стуса

ORCID: 0000-0003-3650-5935

t.oriekhova@donnu.edu.ua

\section{ИССЛЕДОВАНИЕ ИННОВАЦИОННОГО РАЗВИТИЯ В АГРОПРОМЫШЛЕННОМ ПРОИЗВОДСТВЕ КАК ФАКТОР ОБЕСПЕЧЕНИЯ УСТОЙЧИВОГО РАЗВИТИЯ}

В работе проводится исследование влияния инноваџионного развития агропромышленного производства стран на их устойчивое развитие. За основу анализа были выбраны 24 страны - крупнейшие экспортеры агропромышленной продукиии, расположенные практически на всех континентах, и представляющие разные группь по уровню экономического развития. Путем применения метода кластерного анализа получено три кластера стран: кластер 1 (Аргентина, Бразилия, Болгария, Колумбия, Индия, Индонезия, Латвия, Мексика, Румыния, Таиланд, Туриия, Украина), в который входят страны с преимущественно аграрной экономикой, которые развивается экстенсивным путем развития с низким уровнем урожайности, высокими показателями доли сельскохозяйственных угодий, низким уровнем затрат на инновачии, соответствующим низким уровнем продолжительности жизни населения и ВВП на душу населения; увеличение расходов на инновации в этих странах не имеет эфффективного влияния на рост добавленной стоимости в отраслях агропромышленного производства этой группь стран; кластер 2 (Германия, Япония, Корея, Нидерландь, Швеция, Швейцария), в который входят страны $с$ высокоинновационным агропромышленным сектором, который не имеет системообразующего значения в общей структуре экономики, однако характеризуется высоким уровнем урожайности, низкой долей затрат на ресурсы, высоким уровнем затрат на инновации, и соответственно - высокими стандартами жизни населения: продолжительности жизни, ВВП на душу населения; кластер 3 (Австралия, Канада, Китай, Эстония, США), в который входят страны с индустриальной и постиндустриальной структурой экономики, с высокой численностью населения, соответственно - с экстенсивной модели развития АПК, с высокими стандартами жизни населения, однако с высокими показателями нагрузки на экосистему.

Ключевые слова: инновачионное развитие, устойчивое развитие, сельское хозяйство, агропромышленный комплекс, кластерный анализ.

Рис. -3 , Табл. -9 , Лит. -5 


\section{J. Koroviy,}

postgraduate student of the Department of International Economic Relations,

Vasyl Stus Donetsk National University,

ya.koroviy@donnu.edu.ua

\section{T. Oriekhova,}

Doctor of Economic Sciences, Professor,

Vasyl Stus Donetsk National University

ORCID: 0000-0003-3650-5935

t.oriekhova@donnu.edu.ua

\section{STUDY OF INNOVATIVE DEVELOPMENT IN AGRICULTURAL PRODUCTION AS A FACTOR OF SUSTAINABLE DEVELOPMENT}

The work examines the impact of innovative development of agro-industrial production of countries on their sustainable development. The analysis was based on 24 countries - the largest exporters of agro-industrial products, located on almost all continents, and representing different groups in terms of economic development. By applying the method of cluster analysis, three clusters of countries were obtained: cluster 1 (Argentina, Brazil, Bulgaria, Colombia, India, Indonesia, Latvia, Mexico, Romania, Thailand, Turkey, Ukraine), which includes countries with a predominantly agricultural economy that is developing extensively. through development with low yields, high agricultural land share, low innovation costs, corresponding to low life expectancy and GDP per capita; an increase in spending on innovation in these countries does not have an effective impact on the growth of value added in the agro-industrial sectors of this group of countries; cluster 2 (Germany, Japan, Korea, Netherlands, Sweden, Switzerland), which includes countries with a highly innovative agroindustrial sector, which does not have a systemic importance in the overall structure of the economy, but is characterized by a high level of productivity, a low share of resource costs, and a high level of costs on innovation, and, accordingly, on high living standards of the population: life expectancy, GDP per capita; cluster 3 (Australia, Canada, China, Estonia, USA), which includes countries with an industrial and post-industrial structure of the economy, with a high population, respectively - with an extensive model of agro-industrial complex development, with high living standards of the population, but with high load ecosystem.

Keywords: innovative development, sustainable development, agriculture, agroindustrial complex, cluster analysis.

Fig. -3 , Tabl. -9 , Ref. -5

Постановка проблеми. Сучасний глобальний розвиток характеризується наростаючими тенденціями, що впливають на продовольчу безпеку, бідність і голод, сталість сільського господарства та продовольчих систем, а отже перспективи сталого розвитку в цілому: загальний попит на продукти харчування продовжує зростати, i відбуватиметься це в умовах збільшення дефіциту природних ресурсів та важливих змін у структурі попиту на продукти харчування та сільськогосподарську продукцію. Зміна клімату та посилення конкуренції за природні ресурси продовжуватимуть сприяти деградації та дефіциту природних ресурсів, з негативним впливом на засоби виробництва сільськогосподарської продукції та продовольчу безпеку людей. Динамічні трансформації сільськогосподарського сектору відбуваються в більшості країн з низьким рівнем доходу, що матиме вплив на системи сільськогосподарського виробництва, 
зайнятості, харчування та міграції, що ставить світове суспільство перед викликом знайти способи для подальшого розвитку за цих умов.

Таким чином, серед основних викликів, що стоять перед міжнародної та національною політикою розвитку країн у контексті глобального сталого розвитку одним 3 основних $є$ сталий розвиток продуктивності сільського господарства для задоволення зростаючого попиту, підвищення ефективності використання ресурсів у всьому світі, щоб задовольнити зростаючий та мінливий попит на продовольство, а також зупинити та відновити деградацію навколишнього середовища. Впровадження інноваційних стратегій підприємствами АПК $є$ основним рушієм зростання продуктивності та сталого використання ресурсів.

Аналіз останніх досліджень і публікацій. Вагомий внесок у дослідження проблеми інноваційного розвитку підприємств агропромислової сфери було зроблено такими вітчизняними і зарубіжними вченими, як: Л. Антонюк, О. Кузьмін, І. Тараненко, Х. Такеучі, Л. Хітт, I. Фішер, Д. Форей, Й. Шумпетер, О. Яценко та інші. Питанням глобального сталого розвитку присвячені роботи таких вчених, як: Т. В. Орєхова, Б. В. Буркинський, Л. Г. Мельник, Б. С. Патон, В. Я. Шевчук та багато інших.

Формулювання цілей статті. Незважаючи на численні наукові праці як зарубіжних, так і вітчизняних вчених, потребують подальшого наукового опрацювання питання формування інноваційний стратегій підприємства АПК у контексті проблем глобального сталого розвитку, що зумовило вибір теми, постановку мети даної роботи, яка полягає у визначенні впливу інноваційного розвитку в агропромисловому виробництві на забезпечення сталого розвитку в залежності від моделі державної політики інноваційного розвитку країни в цілому.

3 метою дослідження впливу інноваційного розвитку країн (таблиця 1), розвитку агропромислового виробництва на їх сталий розвиток проведемо угрупування 3 використанням методу кластерного аналізу по ряду показників, що представлено у таблиці 2.

Таблиця 1

Коди країн

\begin{tabular}{|c|c|c|c|c|c|}
\hline $\begin{array}{c}\text { Country } \\
\text { Name }\end{array}$ & $\begin{array}{c}\text { Country } \\
\text { Code }\end{array}$ & $\begin{array}{c}\text { Country } \\
\text { Name }\end{array}$ & $\begin{array}{c}\text { Country } \\
\text { Code }\end{array}$ & $\begin{array}{c}\text { Country } \\
\text { Name }\end{array}$ & $\begin{array}{c}\text { Country } \\
\text { Code }\end{array}$ \\
\hline Argentina & ARG & $\begin{array}{c}\text { European } \\
\text { Union }\end{array}$ & EUU & Netherlands & NLD \\
\hline Australia & AUS & Germany & DEU & Romania & ROU \\
\hline Brazil & BRA & India & IND & Sweden & SWE \\
\hline Bulgaria & BGR & Indonesia & IDN & Switzerland & CHE \\
\hline Canada & CAN & Japan & JPN & Thailand & THA \\
\hline China & CHN & Korea, Rep. & KOR & Turkey & TUR \\
\hline Colombia & COL & Latvia & LVA & Ukraine & UKR \\
\hline Estonia & EST & Mexico & MEX & United States & USA \\
\hline
\end{tabular}

За базу аналізу було обрано країни - найбільші експортери агропромислової продукції (Аргентина, Австралія, Бразилія, Болгарія, Канада, Китай, Колумбія, Естонія, СB в цілому, Німеччина, Індія, Індонезія, Японія, Південна Корея, Латвія, Мексика, Нідерланди, Румунія, Швеція, Швейцарія, Тайланд, Туреччина, Україна, США), які розташовані практично на всіх континентах за виключенням Африки, та представляють групи розвинутих країн, країн, що розвиваються та країни із транзитивною економікою [3]. 
Таблиця 2

Сукупність показників дослідження

\begin{tabular}{|c|c|c|}
\hline Показник & Позначення & Значення \\
\hline Food production index & $\mathrm{X} 1$ & Індекс виробництва продуктів харчування \\
\hline $\begin{array}{l}\text { Agriculture, forestry, and fishing, } \\
\text { value added per worker (constant } \\
2010 \text { US\$) }\end{array}$ & $\mathrm{X} 2$ & $\begin{array}{l}\text { Індекс виробництва доданої вартості у галузях } \\
\text { сільського господарства, лісництва та рибництва на } \\
\text { душу співробітників галузі(в \$, в цінах } 2010 \text { року) }\end{array}$ \\
\hline $\begin{array}{l}\text { Agriculture, forestry, and fishing, } \\
\text { value added ( } \% \text { of GDP) }\end{array}$ & $\mathrm{X} 3$ & $\begin{array}{l}\text { Індекс виробництва доданої вартості у галузях } \\
\text { сільського господарства, лісництва та рибництва у \% до } \\
\text { ВВП. (\% від ВВП) }\end{array}$ \\
\hline Cereal yield (kg per hectare) & $\mathrm{X} 4$ & Урожайність (кг з 1 га) \\
\hline Agricultural land (\% of land area) & $\mathrm{X} 5$ & Частка сільськогосподарських угідь (\% загальної площі) \\
\hline $\begin{array}{l}\text { CO2 emissions (metric tons per } \\
\text { capita) }\end{array}$ & X6 & Викиди CO2 \\
\hline GDP per capita (current US\$) & $\mathrm{X} 7$ & ВВП на душу населення \\
\hline $\begin{array}{l}\text { Research and development } \\
\text { expenditure (\% of GDP) }\end{array}$ & $\mathrm{X} 8$ & Витрати на інновації (\% від ВВП) \\
\hline $\begin{array}{l}\text { Life expectancy at birth, female } \\
\text { (years) }\end{array}$ & $\mathrm{X} 9$ & Тривалість життя жінок \\
\hline $\begin{array}{l}\text { Life expectancy at birth, male } \\
\text { (years) }\end{array}$ & $\mathrm{X} 10$ & Тривалість життя чоловіків \\
\hline
\end{tabular}

Показники X2, X3, X7 містили інформацію до 2019 року включно, проте інші показники потребували апроксимації та пролонгації значень до 2019 року . Для отримання даних по обраній системі показників за 24 країнами було побудовано систему прогнозних моделей засобами статистичного програмування мовою $\mathrm{R}$ із застосуванням оболонки R Studio. Було побудовано 168 авторегресійних моделей (7 показників по 24 країнах), серед яких переважна кількість проявляла авторегресію 1 порядку, деякі демонстрували більш глибоку авторегресію 2-3 порядків. Для вибору оптимальної моделі для кожного показника по кожній країні розглядалася сукупність моделей та методів прогнозування: Юла-Уокера (yule-walker та yw), Бурга (burg), метод найменших квадратів (ols), метод максимальної правдоподібності (mle). Для підвищення якості прогнозу при апроксимації для показників, які потребували пролонгації на 3 роки вперед, було обрано двокроковий алгоритм. Спочатку прогнозування відбувалося на 2017 рік, а потім за даними 1995-2017 рр. підбиралася нова оптимальна модель, яка дозволяла спрогнозувати на 2018 та 2019 рр [4].

Для з'ясування однорідності виділеної сукупності країн за обраною сукупністю показників було проведено кластерний аналіз засобами пакету Statistica 10 Enterprise. Для проведення кластеризації країн по обраній сукупності показників було використано спрогнозовані дані на 2019 рік, наведені у таблиці 3. На першому кроці було використано метод дереподібної кластеризації, в результаті чого було отримано дендрограму (рис. 1).

Деревоподібна кластеризація була здійснена за методом Уарда 3 евклідовою метрикою. 
Статистична база кластеризації країн за 2019 рік

\begin{tabular}{|c|c|c|c|c|c|c|c|c|c|c|}
\hline & $\begin{array}{l}\text { Food } \\
\text { product } \\
\text { ion } \\
\text { index } \\
\end{array}$ & $\begin{array}{l}\text { value added per } \\
\text { worker }\end{array}$ & $\begin{array}{l}\text { value } \\
\text { added } \\
(\% \text { of } \\
\text { GDP) }\end{array}$ & $\begin{array}{l}\text { Cereal } \\
\text { yield } \\
\text { (kg per } \\
\text { hectare } \\
\text { ) }\end{array}$ & $\begin{array}{l}\text { Agricultura } \\
1 \text { land (\% of } \\
\text { land area) }\end{array}$ & $\begin{array}{l}\mathrm{CO} 2 \\
\text { emissions } \\
\text { (metric tons } \\
\text { per capita) }\end{array}$ & $\begin{array}{l}\text { GDP per } \\
\text { capita } \\
\text { (current } \\
\text { US\$) }\end{array}$ & $\begin{array}{l}\text { Resear } \\
\text { ch and } \\
\text { develo } \\
\text { pment } \\
\text { expend } \\
\text { iture } \\
(\% \text { of } \\
\text { GDP) } \\
\end{array}$ & $\begin{array}{l}\text { Life } \\
\text { expectanc } \\
\text { y at birth, } \\
\text { female } \\
\text { (years) }\end{array}$ & $\begin{array}{l}\text { Life } \\
\text { expectanc } \\
\text { y at birth, } \\
\text { male } \\
\text { (years) }\end{array}$ \\
\hline ARG & 116 & 1855009,38 & 7,20 & 4770 & 53,50 & 4,44 & 10006,15 & 0,53 & 79,90 & 73,10 \\
\hline AUS & 99 & 72841,58 & 2,09 & 2310 & 51,70 & 16,20 & 54907,1 & 1,85 & 84,90 & 80,80 \\
\hline BRA & 128 & 13775,65 & 4,44 & 4671 & 33,40 & 2,15 & 9737,601 & 1,26 & 79,50 & 72,10 \\
\hline BGR & 118 & 11462,76 & 3,19 & 4677 & 47,50 & 6,15 & 8717,186 & 0,73 & 78,40 & 71,60 \\
\hline CAN & 109,5 & 99708,37 & 1,86 & 3678 & 6,97 & 15,45 & 46194,73 & 1,62 & 84,20 & 80 \\
\hline CHN & 128 & 4188,38 & 7,11 & 6035 & 55,30 & 6,67 & 81993,73 & 2,10 & 79,20 & 74,70 \\
\hline $\mathrm{COL}$ & 111,5 & 6153,16 & 6,74 & 3898 & 39,30 & 1,81 & 10261,68 & 0,23 & 79,90 & 74,50 \\
\hline EST & 123 & 33383,20 & 2,88 & 3333 & 22,30 & 12,45 & 6432,388 & 1,39 & 82,80 & 74 \\
\hline EUU & 99,9 & 28935,62 & 1,64 & 4973 & 39,80 & 6,75 & 46258,88 & 2,14 & 83,64 & 78,40 \\
\hline $\mathrm{DEU}$ & 104 & 49232,78 & 0,82 & 6857 & 48,10 & 9,28 & 23659,87 & 3,01 & 83,10 & 78,40 \\
\hline IND & 134 & 1978,33 & 15,96 & 2955 & 60,47 & 1,82 & 34843,3 & 0,67 & 70,10 & 68,50 \\
\hline IDN & 135 & 4052,04 & 12,72 & 5039 & 30,50 & 1,84 & 4135,569 & 0,19 & 73,80 & 69,50 \\
\hline JPN & 97 & 24600,00 & 1,24 & 6011 & 12,60 & 9,60 & 2104,146 & 3,23 & 87,40 & 81 \\
\hline KOR & 100,7 & 19907,54 & 1,69 & 6357 & 18,20 & 11,50 & 40246,88 & 4,62 & 85,30 & 79,90 \\
\hline LVA & 135,5 & 19850,08 & 3,72 & 3725 & 30,00 & 3,47 & 31761,98 & 0,59 & 79,80 & 70 \\
\hline MEX & 117 & 6057,27 & 3,47 & 3592 & 54,77 & 4,02 & 17836,36 & 0,33 & 77,84 & 72,20 \\
\hline NLD & 114 & 88094,05 & 1,66 & 8178 & 55,00 & 10,55 & 9863,073 & 2,07 & 83,30 & 80,20 \\
\hline ROU & 97 & 6547,77 & 4,10 & 3191 & 60,25 & 3,60 & 52447,83 & 0,49 & 79,10 & 71,40 \\
\hline SWE & 99,8 & 108587,62 & 1,44 & 5458 & 7,53 & 4,25 & 12919,53 & 3,37 & 84,20 & 80,90 \\
\hline CHE & 103,4 & 29726,24 & 0,65 & 6349 & 38,66 & 4,10 & 51610,07 & 3,32 & 85,50 & 81,50 \\
\hline THA & 11 & 3288,28 & 8,00 & 3137 & 42,30 & 3,90 & 7808,193 & 1,10 & 81,00 & 73,60 \\
\hline TUR & 124 & 16808,73 & 6,43 & 3072 & 50,35 & 4,30 & 9042,493 & 0,94 & 80,50 & 74,60 \\
\hline UKR & 142 & 5514,97 & 9,01 & 3688 & 71,60 & 6,00 & 3659,031 & 0,45 & 76,50 & 66,35 \\
\hline USA & 114 & 81000,00 & 0,90 & 7330 & 44,80 & 16,50 & 65118,36 & 2,79 & 81 & 75,95 \\
\hline
\end{tabular}

Для проведення кластеризації вхідні дані були попередньо стандартизовані за наступною формулою:

$$
z_{i}=\frac{\chi_{i}-\bar{\chi}}{\mathrm{s}}
$$

де $\chi_{i}(\mathrm{i}=1 ; \mathrm{n})$ - вхідні значення показника;

$\bar{\chi}=\frac{\sum_{i=1}^{n} \chi_{i}}{n}-$ середнє значення показника;

$s=\sqrt{\frac{\sum_{i=1}^{n}\left(\chi_{i}-\bar{\chi}\right)^{2}}{n-1}}-$ стандартне відхилення показника. 
Отримана дендрограма наочно доводить неоднорість виділених країн по обраній сукупності показників та виоремлює як мінімум 2 чіткі кластери. Уточнення кількості однорідних кластерів, а також їх властивостей, було проведено за методом кластеризації к-середніх (k-means), що надало можливість знайти три чіткі однорідні кластери, а також з'ясувати їх характерні особливості.

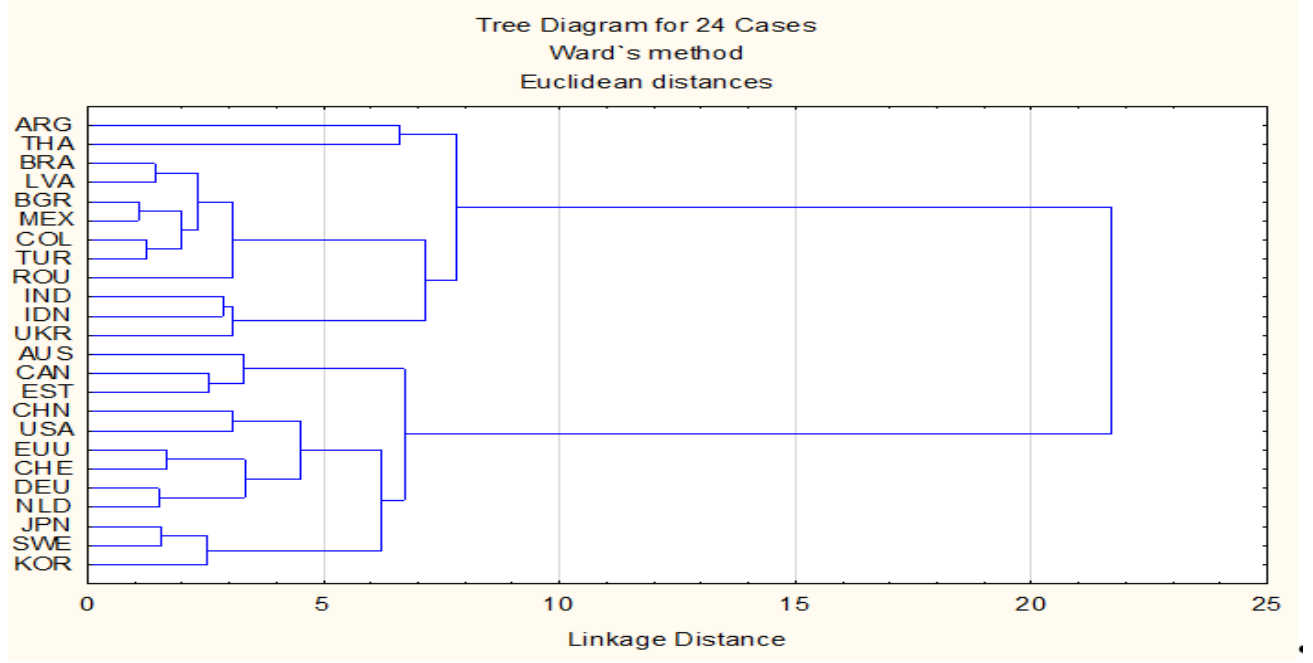

Рисунок 1 - Дендрограма кластеризації 24 країн за обраною сукупністю показників за 2019 рік

За двома кластерами пройшла чітка диференціація обраних 24 країн (рис. 2), проте при підвищенні кількості груп до трьох якість кластеризації збільшилася, що дало змогу виокремити 3 однорідні кластери країн (рис. 3).

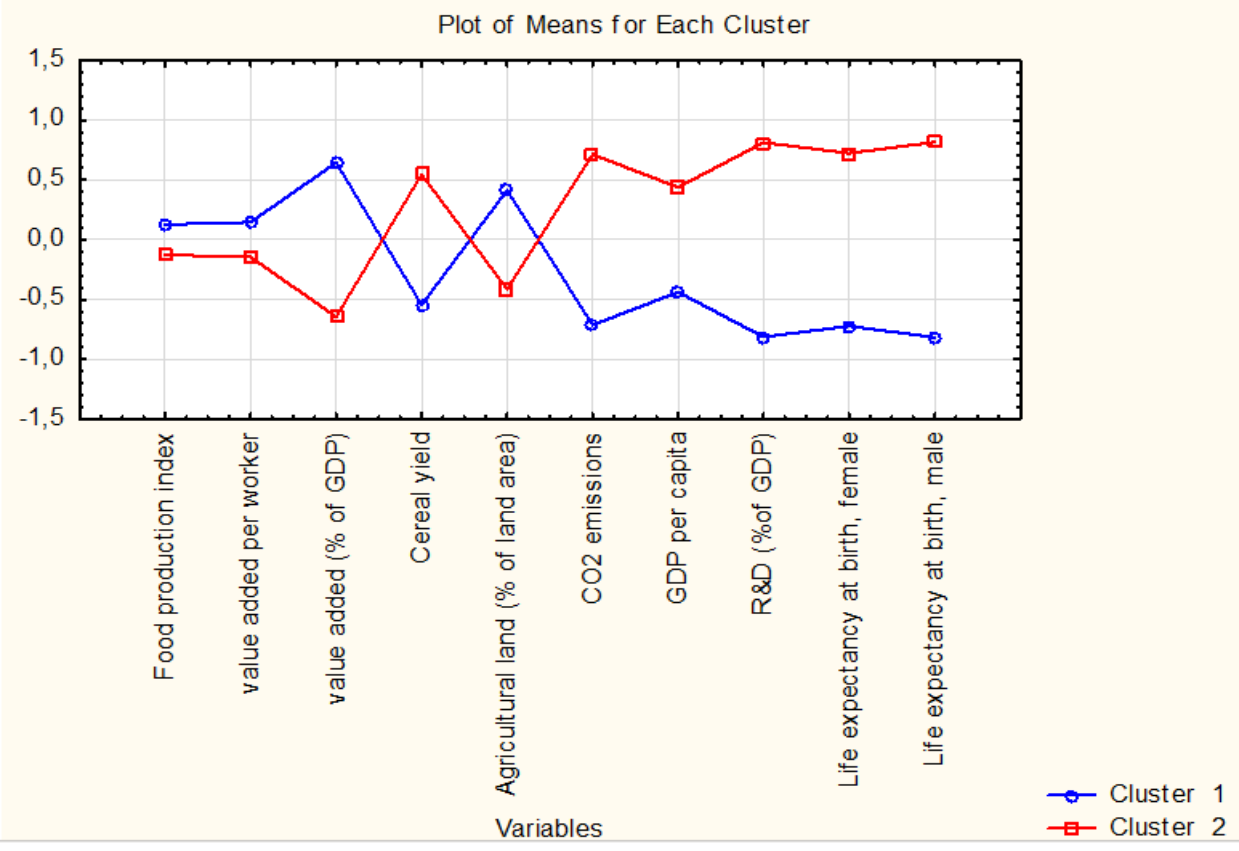

Рисунок 2 - Кластеризація методом k-means за двома кластерами 


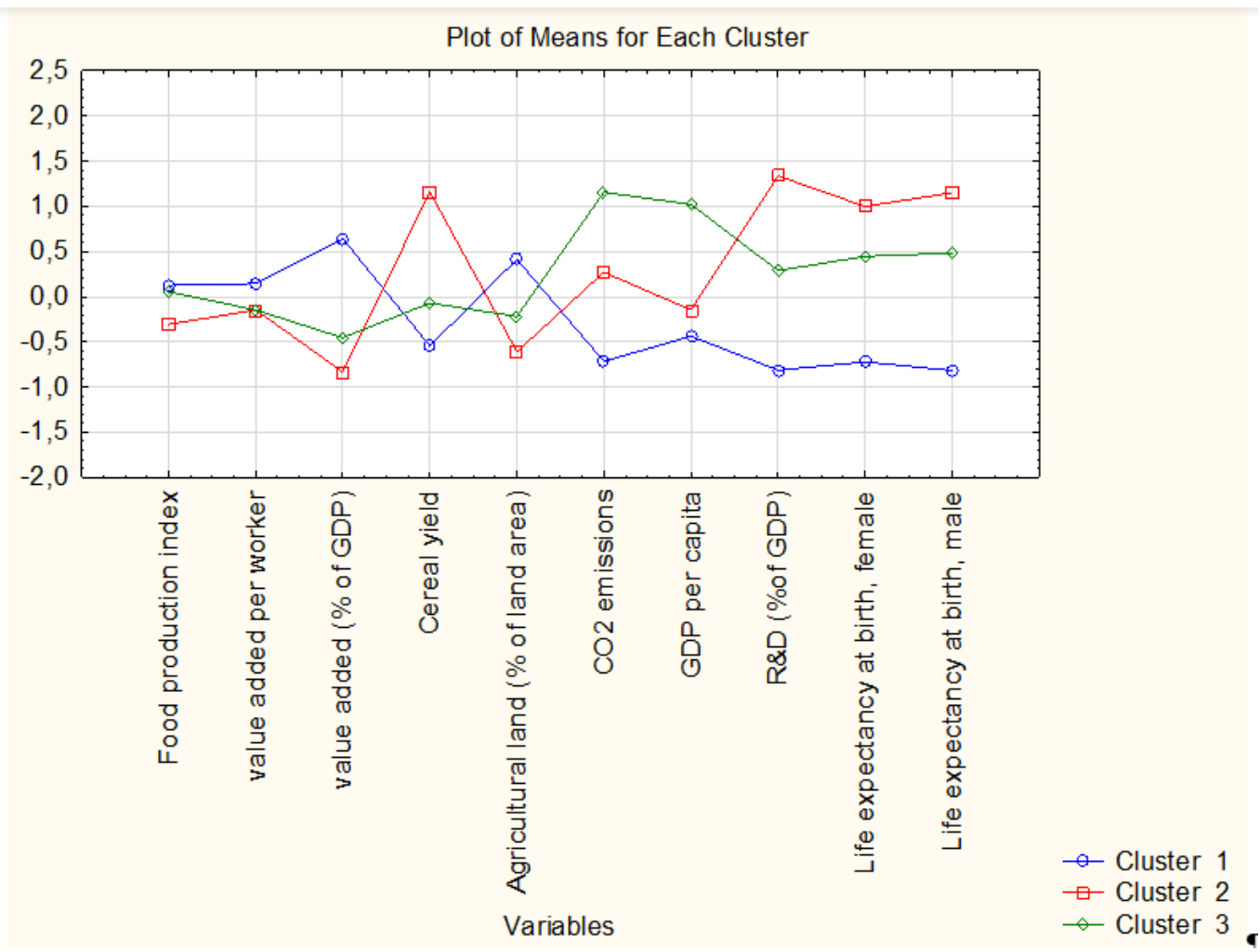

Рисунок 3 - Кластеризація методом k-means за трьома кластерами

Характеристики кожного кластера та їх членів наведені у таблицях $4-6$.

Таблиця 4

Характеристики кластеру 1

\begin{tabular}{|c|c|c|}
\hline Країна & \begin{tabular}{|c|} 
Відстань від центру \\
кластеру
\end{tabular} & Характеристика кластеру \\
\hline ARG & 1,464559 & \multirow{12}{*}{$\begin{array}{l}\text { Високі показники доданої вартості у галузях сільського господарства, } \\
\text { лісництва та рибництва у \% до ВВП. } \\
\text { Низький рівень урожайності з } 1 \text { га } \\
\text { Високі показники частки сільськогосподарських угідь } \\
\text { Низький рівень викидів СО2 } \\
\text { Низький рівень ВВП на душу населення } \\
\text { Низький рівень витрат на інновації } \\
\text { Низький рівень тривалості життя населення }\end{array}$} \\
\hline BRA & 0,497802 & \\
\hline BGR & 0,430918 & \\
\hline $\mathrm{COL}$ & 0,380874 & \\
\hline IND & 1,095576 & \\
\hline IDN & 0,797829 & \\
\hline LVA & 0,581616 & \\
\hline MEX & 0,362362 & \\
\hline ROU & 0,664356 & \\
\hline THA & 1,352710 & \\
\hline TUR & 0,411573 & \\
\hline UKR & 0,744707 & \\
\hline
\end{tabular}


Таблиця 5

Характеристики кластеру 2

\begin{tabular}{|c|c|c|}
\hline Країна & $\begin{array}{l}\text { Відстань від центру } \\
\text { кластеру }\end{array}$ & Характеристика кластеру \\
\hline DEU & 0,399583 & \multirow{6}{*}{$\begin{array}{l}\text { Низький індекс виробництва продуктів харчування } \\
\text { Низькі показники доданої вартості у галузях сільського господарства, } \\
\text { лісництва та рибництва у \% до ВВП. } \\
\text { Високий рівень урожайності з } 1 \text { га } \\
\text { Низькі показники частки сільськогосподарських угідь } \\
\text { Високий рівень витрат на інновації } \\
\text { Високий рівень тривалості життя населення }\end{array}$} \\
\hline JPN & 0,508632 & \\
\hline KOR & 0,526379 & \\
\hline NLD & 0,711302 & \\
\hline SWE & 0,562004 & \\
\hline CHE & 0,517919 & \\
\hline
\end{tabular}

Таблиця 6

Характеристики кластеру 3

\begin{tabular}{|l||l||l||}
\hline \hline Країна & $\begin{array}{l}\text { Відстань від центру } \\
\text { кластеру }\end{array}$ & Характеристика кластеру \\
\hline AUS & 0,698180 \\
\hline CAN & 0,666519 \\
\hline CHN & 0,899616 & \multicolumn{2}{|||}{$\begin{array}{l}\text { Високі викиди CO2 } \\
\text { Високий рівень ВВП на душу населення }\end{array}$} \\
\hline EST & 0,771535 \\
\hline EUU & 0,448750 \\
\hline USA & 0,733616 \\
\hline
\end{tabular}

Кластерний аналіз дозволив отримати якісні характеристики трьох кластерів країн. Для дослідження кількісних характеристик було здійснено кореляційно-регресійний аналіз. Для цього з кожного кластеру було обрано по одному представнику. 3 першого кластеру було обрано Україну для проведення подальших досліджень по ній, з третього - $\mathrm{CC}$, який є центром кластеру. Відбір такого представника здійснювався на основі відстані до центру кластеру 3 таблиці 4. Для другого кластеру, що являє собою сукупність країн з найбільш стійким розвитком, побудуємо моделі для кожної країни. Статистичну базу системи показників для України наведено у таблиці 7.

Таблиця 7

Статистична база системи показників для України за 1995-2019 рр. [5]

\begin{tabular}{|c|c|c|c|c|c|c|c|c|c|c|}
\hline Роки & Х1 & Х2 & Х3 & Х4 & X5 & Х6 & Х7 & Х8 & Х9 & Х10 \\
\hline 1 & 2 & 3 & 4 & 5 & 6 & 7 & 8 & 9 & 10 & 11 \\
\hline 1995 & 104,70 & 1522,18 & 13,77 & 2512,30 & 72,24 & 8,66 & 935,96 & 1,19 & 72,54 & 61,22 \\
\hline 1996 & 92,67 & 1404,11 & 12,23 & 2010,20 & 72,22 & 8,08 & 872,70 & 1,19 & 72,80 & 61,52 \\
\hline 1997 & 93,25 & 1430,84 & 12,52 & 2490,30 & 72,24 & 6,74 & 991,22 & 1,19 & 73,19 & 62,23 \\
\hline 1998 & 80,11 & 1330,04 & 12,07 & 2109,40 & 71,82 & 6,55 & 835,25 & 1,07 & 73,84 & 63,17 \\
\hline 1999 & 78,04 & 1315,19 & 11,88 & 2002,90 & 71,55 & 6,69 & 635,76 & 0,97 & 73,61 & 62,62 \\
\hline 2000 & 85,18 & 1476,41 & 14,49 & 1950,80 & 71,47 & 6,53 & 635,70 & 0,96 & 73,53 & 62,10 \\
\hline 2001 & 93,87 & 1693,69 & 14,31 & 2729,50 & 71,43 & 6,61 & 780,32 & 1,02 & 73,63 & 62,32 \\
\hline 2002 & 93,93 & 1757,85 & 12,96 & 2752,20 & 71,45 & 6,61 & 878,62 & 1,00 & 74,13 & 62,70 \\
\hline 2003 & 93,04 & 1621,36 & 10,81 & 2278,40 & 71,38 & 7,37 & 1047,50 & 1,11 & 74,06 & 62,64 \\
\hline 2004 & 98,01 & 2008,10 & 10,78 & 2845,20 & 71,38 & 7,24 & 1366,02 & 1,08 & 74,05 & 62,60 \\
\hline 2005 & 101,32 & 2034,95 & 9,13 & 2623,00 & 71,29 & 7,09 & 1826,93 & 1,03 & 73,97 & 62,23 \\
\hline 2006 & 100,67 & 2135,51 & 7,54 & 2427,70 & 71,26 & 6,98 & 2300,77 & 0,95 & 74,06 & 62,38 \\
\hline 2007 & 93,68 & 2083,14 & 6,55 & 2206,70 & 71,23 & 6,91 & 3065,61 & 0,85 & 74,22 & 62,51 \\
\hline
\end{tabular}


Продовження таблиці 7

\begin{tabular}{|c|c|c|c|c|c|c|c|c|c|c|}
\hline 1 & 2 & 3 & 4 & 5 & 6 & 7 & 8 & 9 & 10 & 11 \\
\hline 2008 & 114,62 & 2479,97 & 6,86 & 3486,90 & 71,28 & 6,72 & 3887,24 & 0,85 & 74,28 & 62,51 \\
\hline 2009 & 117,13 & 2486,50 & 7,17 & 3003,80 & 71,25 & 5,65 & 2543,00 & 0,86 & 74,86 & 63,79 \\
\hline 2010 & 107,34 & 2502,74 & 7,45 & 2726,60 & 71,23 & 6,64 & 2965,14 & 0,83 & 75,50 & 65,28 \\
\hline 2011 & 127,55 & 2983,27 & 8,20 & 3753,70 & 71,26 & 6,27 & 3569,76 & 0,74 & 75,88 & 65,98 \\
\hline 2012 & 127,05 & 2948,34 & 7,82 & 3156,80 & 71,29 & 6,49 & 3855,42 & 0,75 & 76,02 & 66,11 \\
\hline 2013 & 156,54 & 3273,77 & 8,79 & 4030,80 & 71,68 & 5,98 & 4029,71 & 0,76 & 76,22 & 66,34 \\
\hline 2014 & 152,73 & 4783,04 & 10,15 & 4400,20 & 71,66 & 5,05 & 3104,64 & 0,65 & 76,37 & 66,25 \\
\hline 2015 & 144,88 & 4419,36 & 12,06 & 4140,90 & 71,65 & 4,35 & 2124,66 & 0,61 & 76,25 & 66,37 \\
\hline 2016 & 169,07 & 4683,38 & 11,73 & 4651,60 & 71,67 & 4,49 & 2187,73 & 0,48 & 76,46 & 66,73 \\
\hline 2017 & 155,00 & 4671,45 & 10,19 & 4315,80 & 71,64 & 5,20 & 2640,68 & 0,45 & 76,78 & 67,02 \\
\hline 2018 & 172,00 & 5233,08 & 10,14 & 3952,00 & 71,62 & 5,70 & 3096,82 & 0,47 & 76,72 & 66,69 \\
\hline 2019 & 160,00 & 5514,97 & 9,01 & 3688,00 & 71,60 & 6,00 & 3659,03 & 0,45 & 76,50 & 66,35 \\
\hline
\end{tabular}

3 метою знаходження зв'язків між системою показників було проведено кореляційний аналіз засобами надбудови Аналіз даних Microsoft Excel. Кореляційну матрицю наведено у таблиці 8

Таблиця 8

Кореляційна матриця системи показників для України (1995-2019 рр)

\begin{tabular}{|c|c|c|c|c|c|c|c|c|c|c|}
\hline & $X 1$ & $X 2$ & $X 3$ & $X 4$ & $X 5$ & $X 6$ & $X 7$ & $X 8$ & $X 9$ & $X 10$ \\
\hline $\mathrm{X} 1$ & 1,00 & & & & & & & & & \\
\hline $\mathrm{X} 2$ & 0,92 & 1,00 & & & & & & & & \\
\hline X3 & $-0,27$ & $-0,26$ & 1,00 & & & & & & & \\
\hline $\mathrm{X} 4$ & 0,96 & 0,89 & $-0,22$ & 1,00 & & & & & & \\
\hline $\mathrm{X} 5$ & 0,01 & $-0,05$ & 0,61 & $-0,05$ & 1,00 & & & & & \\
\hline X6 & $-0,74$ & $-0,76$ & 0,12 & $-0,78$ & 0,18 & 1,00 & & & & \\
\hline $\mathrm{X} 7$ & 0,68 & 0,65 & $-0,81$ & 0,64 & $-0,40$ & $-0,41$ & 1,00 & & & \\
\hline $\mathrm{X} 8$ & $-0,86$ & $\begin{array}{c}-0,94 \\
\end{array}$ & 0,35 & $-0,84$ & 0,25 & 0,82 & $-0,69$ & 1,00 & & \\
\hline $\mathrm{X} 9$ & 0,89 & 0,91 & $-0,41$ & 0,87 & $-0,27$ & $-0,81$ & 0,75 & $-0,94$ & 1,00 & \\
\hline $\mathrm{X} 10$ & 0,89 & 0,89 & $-0,31$ & 0,86 & $-0,14$ & $-0,80$ & 0,68 & $-0,91$ & 0,98 & 1,00 \\
\hline
\end{tabular}

Для дослідження проблем стійкого розвитку країни розглянемо вплив на показники ефективності інших факторів. Так, кореляційна матриця доводить, що:

на фактор Х6 - викиди СО2 достатньо сильно впливають такі фактори:

$\mathrm{X} 1$ (r16=-0,74) - помірний обернений вплив індексу виробництва продуктів харчування

X2 (r26=-0,76) - помірний обернений вплив індексу виробництва доданої вартості у галузях сільського господарства, лісництва та рибництва на душу співробітників галузі

$\mathrm{X} 4$ (r46=-0,78) - помірний обернений вплив урожайності

$\mathrm{X} 8(\mathrm{r} 68=0,82)$ - сильний прямий вплив витрат на інновації

X9 (r69=-0,81) - сильний обернений вплив тривалості життя населення

на фактор X9 - тривалість життя жінок достатньо сильно впливають такі фактори:

$\mathrm{X} 1(\mathrm{r} 19=0,89)$ - сильний прямий вплив індексу виробництва продуктів харчування

$\mathrm{X} 2(\mathrm{r} 29=0,91)$ - сильний прямий вплив індексу виробництва доданої вартості у галузях сільського господарства, лісництва та рибництва на душу співробітників галузі

$\mathrm{X} 4(\mathrm{r} 49=0,87)$ - сильний прямий вплив урожайності

X6 (r69=-0,81) - сильний обернений викидів СО2

X8 (r89=-0,94) - сильний обернений вплив витрат на інновації

Фактор X8 - витрати на інновації має вплив на такі чинники:

$\mathrm{X} 1$ (r18=-0,86) - сильний обернений вплив на індекс виробництва продуктів харчування 
X2 (r28=-0,94) - сильний обернений вплив на індекс виробництва доданої вартості у галузях сільського господарства, лісництва та рибництва на душу співробітників галузі

X4 (r48=-0,84) - сильний обернений вплив на урожайність

X6 (r68=0,82) - сильний прямий вплив на викиди CO2

X9 (r89=-0,94) - сильний обернений вплив витрат на тривалість життя населення

Якісні зв'язки було уточнено за допомогою побудови парних регресійних моделей. Всі отримані моделі є значущими за критеріями Фішера і Стьюдента.

Таблиця 9

\section{Розрахунок впливу факторів на показники сталого розвитку України}

\begin{tabular}{|c|c|c|}
\hline Фактор & Рівняння & Очікувані результати \\
\hline \multirow{2}{*}{$\begin{array}{c}\text { Х6 } \\
\text { Вплив на } \\
\text { зміну } \\
\text { викидів } \\
\text { СО2 } \\
\end{array}$} & $\mathrm{X} 6=9,23-0,00092 \mathrm{X} 4$ & $\begin{array}{l}\text { Збільшення урожайності на } 1 \text { кг з га дозволить зменшити викиди СО2 на } \\
0,92 \text { метричних кг на душу населення }\end{array}$ \\
\hline & $\mathrm{X} 6=3,5+3,39 \mathrm{X} 8-$ & $\begin{array}{l}\text { Збільшення витрат на інновації на 1\% від ВВП призведе до збільшення } \\
\text { викидів СО2 на } 3,39 \text { метричних тон на душу населення }\end{array}$ \\
\hline \multirow{4}{*}{$\begin{array}{c}\text { Х9 } \\
\text { Вплив на } \\
\text { зміну } \\
\text { тривалості } \\
\text { життя } \\
\text { жінок }\end{array}$} & $\mathrm{X} 9=6$ & $\begin{array}{l}\text { Збільшення індексу виробництва продуктів харчування на } 100 \text { одиниць } \\
\text { дозволить збільшити тривалість життя жінок на } 4,4 \text { роки }\end{array}$ \\
\hline & $\mathrm{X} 9=72,34+0,0009 \mathrm{X} 2$ & $\begin{array}{l}\text { Збільшення індексу виробництва доданої вартості у галузях сільського } \\
\text { господарства, лісництва та рибництва на душу співробітників галузі на } \\
1000 \$ \text { дозволить збільшити тривалість життя жінок на } 0,9 \text { років }\end{array}$ \\
\hline & $\mathrm{X} 9=70,54+0,0014 \mathrm{X} 4$ & $\begin{array}{l}\text { Збільшення урожайності на } 1 \text { т } 3 \text { га дозволить збільшити тривалість життя } \\
\text { жінок на } 1,4 \text { роки }\end{array}$ \\
\hline & $\mathrm{X} 9=81,8$ & $\begin{array}{l}\text { Збільшення викидів СО2 на } 1 \text { метричний кг призводить до зменшення } \\
\text { тривалості життя жінок на } 1,1 \text { рік }\end{array}$ \\
\hline \multirow{3}{*}{$\begin{array}{c}\text { Х8 } \\
\text { Вплив } \\
\text { витрат на } \\
\text { інновації } \\
\text { на інші } \\
\text { показники }\end{array}$} & $\mathrm{X} 1=199,6-98,4 \mathrm{X} 8$ & $\begin{array}{l}\text { Збільшення витрат на інновації на 1\% від ВВП призведе до зменшення } \\
\text { індексу виробництва продуктів харчування на 98,4 одиниць }\end{array}$ \\
\hline & $\mathrm{X} 2=7352,6-5385,7 \mathrm{X} 8$ & $\begin{array}{l}\text { Збільшення витрат на інновації на } 1 \% \text { від ВВП призведе до зменшення } \\
\text { індексу виробництва доданої вартості у галузях сільського господарства, } \\
\text { лісництва та рибництва на душу співробітників галузі на 5385,7\$ }\end{array}$ \\
\hline & $X 4=5618-2981 X 8$ & $\begin{array}{l}\text { Збільшення витрат на інновації на 1\% від ВВП призведе до зменшення } \\
\text { урожайності на } 2981 \text { т з га }\end{array}$ \\
\hline
\end{tabular}

Висновки. Таким чином, проведене дослідження дозволило здійснити угрупування країн за моделями інноваційного розвитку агропромислового сектору і відповідного впливу на їх сталий розвиток. Шляхом застосування методу кластерного аналізу отримано три кластери країн: кластер 1 (Аргентина, Бразилія, Болгарія, Колумбія, Індія, Індонезія, Латвія, Мексика, Румунія, Тайланд, Туреччина, Україна), до якого входять країни 3 переважно аграрною економікою, що розвивається за екстенсивним шляхом розвитку з низьким рівнем врожайності, високими показниками частки сільськогосподарських угідь, низьким рівнем витрат на інновації, та відповідним низьким рівнем тривалості життя населення і ВВП на душу населення; збільшення витрат на інновації не має ефективного впливу на зростання доданої вартості у галузях агропромислового виробництва в цій групі країн; кластер 2 (Німеччина, Японія, Корея, Нідерланди, Швеція, Швейцарія), до якого входять країни з високого інноваційним агропромисловим сектором, який не має системо утворюючого значення у загальній структурі економіки, проте характеризується високим рівнем врожайності, низькою часткою витрат на ресурси, високим рівнем витрат на інновації, та відповідно - високими стандартами життя населення: тривалістю життя, ВВП на душу населення; кластер 3 (Австралія, Канада, Китай, Естонія, США), до якого входять країни з індустріальною та постіндустріальною структурою економіки, з високою кількістю населення, відповідно 
- 3 екстенсивною моделлю розвитку АПК, з високими стандартами життя населення, проте з високими показниками навантаження на екосистему.

\section{СПИСОК ВИКОРИСТАНИХ ДЖЕРЕЛ}

1. Carrión-Flores, C. E. \& Innes, R. (2010) Environmental innovation and environmental performance. Journal of Environmental Economics and Management, 59, 1, 27-42.

2. OECD (2002) Dynamising National Innovation Systems. OECD, Paris.

3. OECD (2019) Innovation, Productivity and Sustainability in Food and Agriculture. OECD, Paris

4. World Bank Indicators. URL: https://data.worldbank.org/indicator

5. Державна служба статистики України. URL: http://www.ukrstat.gov.ua

\section{REFERENCES}

1. Carrión-Flores, C. E. \& Innes, R. (2010) Environmental innovation and environmental performance. Journal of Environmental Economics and Management, 59, 1, 27-42.

2. OECD (2002) Dynamising National Innovation Systems. OECD, Paris.

3. OECD (2019) Innovation, Productivity and Sustainability in Food and Agriculture. OECD, Paris

4. World Bank Indicators. URL: https://data.worldbank.org/indicator

5. State Statistics Service of Ukraine. URL: http://www.ukrstat.gov.ua 